\title{
THE TREATMENT OF SWIFT'S DISEASE (Erythrœdema)
}

\author{
BY \\ G. BRUTON SWEET, M.B., Ch.M., \\ Pædiatric Physician, Auckland Hospital, N.Z.
}

At the Australasian Medical Congress held in Auckland in February, 1914, a paper by $\mathrm{H}$. Swift ${ }^{1}$ of Adelaide was read on a condition hitherto undescribed, to which he gave the name 'erythrodema.' This condition, which is now well known to pædiatrists, was graphically described, and the importance of the discovery of a new disease with characteristic signs and symptoms being at once recognized by the members of the Diseases of Children section, it was decided to discuss this condition at the next triennal meeting of Congress. Owing to the War, no meeting was held until 1920, when a paper was read by Wood ${ }^{2}$ who with Cole had collected 91 cases, and it was mentioned that since Swift had drawn attention to this condition, it had been observed in most of the Australian States and that, owing to the red hands and feet, and the fine papular rash on the trunk, it had become known as the 'pink disease.'

In the Archives of Pediatrics in September, 1920, an article appeared by Weston ${ }^{3}$ on a condition called Acrodynia, from a perusal of which it was quite evident that the condition described by Swift in 1914 had been re-discovered in America.

When in America in 1927, the writer found that Bilderback ${ }^{4}$ of Portland, Oregon, had first drawn attention to the disease in that country, and had read a paper on the subject to a local pædiatric society, being at the time unaware that the disease had been previously described. The cases mentioned in Weston's article were those of Bilderback, though curiously enough, his name was never mentioned in connection with them, but only that of Patrick, his assistant. The writer also learned that the priority of Swift as the discoverer of this interesting disease was well recognized throughout America; and it was considered that none of the above three names by which it was designated was satisfactory or descriptive of a condition that had other and perhaps more striking symptoms than those from which the titles had been drawn. A general wish was there expressed that the new disease should be called by the name of the man who first discovered it.

The disease has now been recognized in many parts of Europe, and among writers who have described it are Feer ${ }^{5}$ of Zurich, who called it neurosis of the neuro-vegetative system, and Thursfield and Paterson ${ }^{6}$ of London who designated it ' dermato-polyneuritis.'

Before proceeding to discuss the treatment which is recommended, it would perhaps not be out of place to mention the svmptoms of this chronic disease. 
When it has fully developed, the symptoms and signs are so characteristic that any observer who has once seen a case could not fail to diagnose the condition in the future. The red hands and feet, slightly swollen but not œdem itous, as Swift would seem to imply, are characteristic of no other condition, but are not always present in the early signs of the disease. As a general rule the onset is insidious, but in two of the writer's cases, the disease commenced suddenly with an elevation of temperature, and the appearance of the fine papular eruption on the trunk caused it to be mistaken for scarlet fever. Profuse sweating, and the rash just mentioned occur in all cases, and the skin feels cold and clammy.

The most distressing symptoms are the marked irritability in temper, and an insomnia which is always present, with the result that in a few weeks the mother of the patient and other inmates of the home become nervous wrecks. The facial appearance of the patient is one of abject misery, nothing amuses or interests him, and he is constantly rubbing his hands together or scratching his body to relieve the persistent itching. Photophobia is commonly but not always present, and the characteristic decubitus is lying face downward with the head burrowed into the pillow. Nasal and bronchial catarrh, though not always present, is common in the early stages of this complaint, and rhinorrhoea and a distressing cough frequently persist for weeks or months on end. Anorexia is usual ; at other times the appetite is unaffected but in all cases the child steadily loses weight.

Wasting of the voluntary muscles is always present, and as a result the child refuses to stand or walk, preferring also a recumbent to a sitting posture. Alopecia and loss of some of the finger and toe nails is not uncommon, and in some cases ulcerative stomatitis occurs, and the temporary teeth drop out. As a result of the irritation, abrasions of the skin are common, and at some stage of the disease desquamation of the cutaneous covering of the fingers and toes always occurs.

All who are familiar with Swift's disease must agree that there is no more pathetic condition in the ailments from which children suffer than a well marked case of this complaint. Swift's disease is essentially a chronic condition. Wood states 'it can be said that the child's symptoms will almost certainly last for three or four months from the commencement of the illness and may last as long as thirteen months before it passes completely away.'

The prognosis as legards life is favourable but several deaths from the disease have been reported, and also from intercurrent affections such as pneumonia. Hospital treatment is unsatisfactory, and two of the cases in the present series were getting steadily worse and had to be removed to their own homes before improvement occurred. The Medical Superintendent of the Royal Alexandra Hospital in Sydney informed the writer that he always gave a guarded prognosis to parents of children suffering from pink disease, and statistics for the years 1927 and 1928 show a mortality of 15 out of 61 cases admitted during the two years, - a death rate of 24.5 per cent.

The age incidence of the disease is that of infancy or very early childhood, and only a very few cases of older children have been described. 
The ætiology is obscure but the general opinion of observers is in favour of an infection by a micro-organism not yet isolated. The possibility of its being a deficiency disease cannot altogether be disregarded, as in some respects, for example the skin lesions, it resembles pellagra, and in others, e.g., the wasting of muscles and great irritability of the nervous system, the polyneuritis of beri-beri.

Treatment.-Until the ætiology of this interesting disease has been placed on a sound footing, the treatment must of necessity be symptomatic. It should be directed towards combating the insomnia, general nervous irritability, loss of muscular tone, hyperhidrosis, and skin irritation.

It may be stated at the onset that sedatives or hypnotics are of little, if any, value. The experience of Wood, that even large doses of opium, bromides or other hypnotics failed to produce sleep, is amply borne out by all observers of this condition. He advises methylated spirits to be applied to the skin of the body,followed by a dusting powder to relieve the skin irritation, and the application of weak tincture of iodine to the skin of the hands and feet.

General treatment of a tonic nature is advised, such as living in the open air and the administration of cod-liver oil and malt. Swift recommends a regular course of massage for the wasted muscles. It is the experience of most physicians who have treated cases of Swift's disease, that the palliative measures just mentioned do little to relieve the symptoms of the little patients, or the extreme anxiety of the parents, who, worried by the loss of sleep, are usually in a highly nervous condition.

In December, 1924, the writer ' treated a case of three and a half months' duration with light treatment from a mercury-vapour lamp, with extremely happy results, and this and two other cases which alike responded to the treatment were reported. A further series of four cases was reported to the diseases of children section of the Australasian Medical Congress held in Dunedin in 1926, and the opinion was then expressed that this form of treatment was a specific for this condition.

Since then ten or more cases have been treated with most satisfactory results ; indeed the writer has received more gratitude from parents of children who were suffering from Swift's disease than almost any other condition he has treated, and he has in consequence had no reason to alter the opinion expressed four years ago.

The technique adopted for the first case has been used throughout. The patient is stripped and exposed to the rays of a radiant-heat lamp for five minutes and when thoroughly warmed by the rays, is exposed for three minutes to the mercury-vapour lamp at a distance of 90 to 100 centimetres. The carbon filament is kept going during the exposure to the mercury vapour lamp and while the child is being dressed. The treatment is continued at intervals of three days, and on each occasion the time of exposure to the ultra-violet rays is lengthened and the distance of the patient from the lamp reduced. No other treatment is given except for diarrhoea or constipation, one or other of which symptoms are commonly present.

The average number of light treatments before the cure is complete is. nine. 
The first symptom to be relieved is the insomnia; and usually about the same time the sweating and rash on trunk subside. The child then begins to take an interest in people and surrounding objects and becomes more alert and happy. The last signs to disappear are the redness of hands and feet and muscular weakness.

TABLE 1.

Simuary of cases treated.

\begin{tabular}{|c|c|c|c|c|}
\hline Case & $\begin{array}{c}\text { Age } \\
\text { (months) }\end{array}$ & $\begin{array}{l}\text { Iength of } \\
\text { previous } \\
\text { illness }\end{array}$ & $\begin{array}{l}\text { No. of } \\
\text { treatments } \\
\text { before } \\
\text { recovery }\end{array}$ & Remarks \\
\hline 1 & $9 \frac{1}{2}$ & $2 \frac{1}{2}$ months & 10 & Improvement after first treatment. \\
\hline 2 & 16 & $2 \frac{1}{2}$ months & 10 & Almost well after 6 exposures. \\
\hline 3 & 17 & 1 month & 9 & $\begin{array}{l}\text { Commenced with marked photophobia. Rash } \\
2 \text { weeks later. }\end{array}$ \\
\hline 4 & $44_{2}^{1}$ & 4 weeks & 10 & Early and rapid improvement. \\
\hline 5 & $11 \frac{3}{4}$ & 1 month & 9 & $\begin{array}{l}\text { Gained weight during treatment, which is } \\
\text { unusual. }\end{array}$ \\
\hline 6 & 17 & 9 months & 10 & $\begin{array}{l}\text { Emaciated; wt. } 13 \text { lb. Ulcerated buttocks, } \\
\text { photophobia and diarrhœea. Steady progress } \\
\text { with treatment. }\end{array}$ \\
\hline 7 & 10 & 2 weeks & 11 & $\begin{array}{l}\text { Response to treatment not so rapid, possibly } \\
\text { because it was an early case. }\end{array}$ \\
\hline 8 & 10 & 3 weeks & 9 & Quite well after 7 exposures. \\
\hline 9 & 6 & 1 week & 8 & $\begin{array}{l}\text { Improvement after lst treatment. Slept } 3 \text { hours } \\
\text { the first night. Hands and feet normal after } \\
7 \text { treatments. }\end{array}$ \\
\hline 10 & 14 & 5 months & 24 & Treatments interrupted. Case reported in full. \\
\hline 11 & 18 & 3 weeks & 13 & $\begin{array}{l}\text { Had ulcerative stomatitis and lost } 4 \text { teeth, } \\
\text { prolapse of rectum : recovered. }\end{array}$ \\
\hline 12 & 23 & 5 weeks & 6 & $\begin{array}{l}\text { Was at first considered to be poliomyelitis. } \\
\text { Typical signs } 2 \text { weeks later. Rapid improve- } \\
\text { ment. }\end{array}$ \\
\hline 13 & 21 & 7 months & 7 & $\begin{array}{l}\text { After 2nd treatment slept at night for first time } \\
\text { for months. After that, improvement rapid. }\end{array}$ \\
\hline 14 & 17 & $5_{2}^{1}$ months & 7 & $\begin{array}{l}\text { At end of treatment, quite well except that } \\
\text { hands and feet were still rather red. }\end{array}$ \\
\hline 15 & 12 & 2 months & 5 & $\begin{array}{l}\text { Commenced with photophobia and lachryma- } \\
\text { tion, rapidly lost weight and had insomnia, } \\
\text { rash and sweating. Improvement after first } \\
\text { treatment. }\end{array}$ \\
\hline 16 & 12 & 4 weeks & 7 & A mild case, easily cured. \\
\hline 17 & 17 & 8 months & 7 & $\begin{array}{l}\text { A long history. Early rapid improvement with } \\
\text { treatment. }\end{array}$ \\
\hline
\end{tabular}


Two rather interesting facts were noticed during the course of treatment : first, that though nurses and patients who were holding the child frequently had erythema from the ultra-violet rays, the patients, although nearer the lamp, never suffered in this respect; and secondly, that with rare exceptions although in every other way the child improved as the course of treatment progressed, the weight did not rise but often fell until the treat. ment was discontinued.

The number of cases treated is admittedly small, but no case seen in private practice has been excluded, and the results have been entirely satisfactory in all cases except one, which, though it ultimately got well, relapsed while under treatment and is therefore reported. Two other cases were under treatment at the time the paper was written, but are not included in the series quoted.

Joan, aged 14 months (('ase 10 in series). First seen on January 17 th, 1929. She had been a healthy baby until age of 9 months, then developed diphtheria and was in hospital for one month; soon after developed pertussis (?) and a rash, and has never had a good night's rest since. Eight weeks after, condition was diagnosed scarlet fever and was in hospital for 7 weeks ; discharged a week ago with rash still present and body, feet and hands still desquamating. When first seen she was very irritable and constantly rubbing hands and feet together; sweated a great deal, slept very little day or night. Bowels loose, took food well : had rhinorrhœea and troublesome cough. Weight $15 \mathrm{lb}$. 14 ounces, nutrition and tissue turgor very poor, 16 teeth, rose-coloured papular rash all over body : skin cold and clammy : hands and feet red in colour, skin of fingers and toes desquamating.

Treatuent: Artificial sunlight was commenced at once.

On Jan. 31st it was noticed that all the lower incisor teeth were loose.

Feb. 14th. Much better, rash has disappeared and the child is sleeping all night.

Feb. 28th. Rash has returned and sleep is again bad.

From this date although treatment was continued and a new burner used in the mercury vapour lamp, there was little improvement in the condition until May 15th when all symptoms had disappeared.

On May 25th she developed an extensive impetigo of face and enlargement of submaxillary lymph nodes and two days later she was sent to hospital for treatment of the suppurative adenitis. Abscesses on both sides were evacuated and the impetigo which was extensive was treated. During her stay in hospital the rash, irritability and insomnia returned.

She was discharged from hospital on June 20th in an extremely emaciated condition, and treatment which had been discontinued while in hospital was started again.

July 18th. All symptoms had disappeared. She was eating and sleeping well; 6 teeth were missing from the lower jaw and she was extremely thin but otherwise well. After this date improvement and gains in weight were rapid.

This case is reported as being the only one in the series in which relapses occurred.

It is more or less typical of severe cases of the condition met with prior to artificial sunlight being adopted as a method of treatment, and the writer is unable to explain why the treatment was ineffective in guarding against a relapse.

\section{Summary.}

A brief history :s given of the interesting disease known as erythrœedema, acrodynia, the pink disease, dermato-polyneuritis and other names, and the opinion expressed that in future it should be named Swift's disease. 
Treatment by artificial sunlight is advocated and results obtained in seventeen consecutive cases is given.

No opinion is expressed as to the manner in which a cure is effected or whether the curative agent lies in the short ultra-violet rays, or in a combination of these with the infra-red and luminous rays, for in all cases the latter were used in conjunction with the former.

\section{REFERENCES.}

1. Swift, H., Tr. Australasian Med. Cong., Brisbane, 1914, 347.

2. Wood, A. J., Ibid., 1920, 444.

3. Weston, W., Arch. Ped., N.Y., 1920, XXXVII, 513.

4. Bilderback, J. B., Northwest med.; Seattle, 1920, XIX, 263.

5. Feer, E., Jahrb, f. Kinderh, Berlin, 1925, CVIII, 267

6. Thursfield, J. H., \& Paterson, D. P., Brit. J. Ch. Dis., Lond., 1922, XIX, 27.

7. Sweet, G. B., Arch. Ped., N.Y., 1925, XLII, 543. 